\title{
CARDIOVASCULAR RISK ASSESSMENT BY FRAMINGHAM SCORE PRE AND POST KIDNEY TRANSPLANT
}

\author{
Estratificação de risco cardiovascular pré e pós-transplante pela escala de Framingham
}

Marcos Vinicius de Sousa, Nayara Tenório, Carla Feitosa do Valle, Marilda Mazzali.

\begin{abstract}
Cardiovascular mortality is the main cause for graft loss after a successful kidney transplant. Purpose: To analyze the risk for cardiovascular events by the Framinghan risk score, pre and 1-year after kidney transplant. Methods: Retrospective study analyzing the transplant Unit database of kidney transplants performed from January 2010 to January 2012. Inclusion criteria: age >18 years old, functioning graft 12 months post-transplant. Exclusion criteria: patient death or graft loss within the first year after transplant. Demographic and laboratory data were collected pre and 12 months post-transplant; the Framinghan risk score was calculated at those points. Pre-transplant echocardiogram was also analyzed. Results: From 230 kidney transplants performed during the studied period, 167 fulfilled the inclusion criteria. Sixty-three were excluded due to death or graft loss $(n=29)$ or insufficient data for analysis. In the majority, the studied group was male (64.6\%), mean age of $47.9 \pm 11.1$ years old and recipients from deceased donor (97\%). Echocardiogram showed a $67.5 \pm 6.6 \%$ ejection fraction, left ventricular hypertrophy in $98 \%$, with a low incidence of valvar calcification (2.5\%). Framinghan score was similar pre and after transplant (16.4 \pm 14.9 vs. $18.3 \pm$ 17.2, $p=n s)$. However, analysis of isolated parameters showed a significant difference pre and after transplant. While pre-transplant risk factors were high blood pressure, lower HDL cholesterol, and active smoking, post-transplant risk factors were the occurrence of diabetes, higher total cholesterol that required anti-hypertensive therapy. Conclusion: the early after transplant results, recovery of renal function, hematocrit and nutritional levels in the body weight gain usually along with impaired metabolic parameters, mainly total cholesterol, triglyceryde and uric acid maintained a similar Framinghan risk score as pre-transplant levels.
\end{abstract}

Keywords: Cardiovascular Disease; Transplant; Risk Assessment.

Institution

Programa de Transplante Renal, Disciplina de Nefrologia, DCM/FCM

Unicamp. Laboratório de Investigação em Transplante (LINT)- FCM

Unicamp.

\section{Correspondence:}

Marilda Mazzali

Laboratory of Investigation in Transplantation - FCM UNICAMP

Rua Tessália Vieira de Camargo, 126 - Cidade Universitária

Zeferino Vaz - CEP 13083-970 - Campinas/SP- Brazil

E-mail: marildamazzali@gmail.com

Phone: (55) 19 3521-8204

Recebido em: 18/03/2016

Aceito em: $27 / 04 / 2016$

\section{INTRODUCTION}

Patients with chronic kidney disease (CKD) have an increased risk for cardiovascular disease, with a prevalence of coronary disease of $40 \%$ and $75 \%$ left ventricular hypertrophy. ${ }^{1}$ Compared to global population, cardiovascular mortality is 10 to 20 times higher in patients with CKD on dialysis, corresponding to 40 to $60 \%$ of all-cause mortality. ${ }^{2,3}$ 
Kidney transplant is considered the therapy of choice for CKD, with improvement in the quality of life and improvement in the patient and graft survival. However, cardiovascular mortality with a functioning graft has been the main cause for late graft loss. ${ }^{4-6}$ The incidence of cardiovascular events is higher within the first three months after transplant with a progressive reduction over time. Aalten et al showed that after 10 years of transplant, around $40 \%$ of patients presented at least one cardiovascular event ${ }^{7}$

The increased incidence of cardiovascular events can be explained by the presence of traditional risk factors, such as systemic hypertension ( 70 to $85 \%$ ), hyperlipidemia (35 to $60 \%$ ) and diabetes (10 to $30 \%))^{8,9}$ Additionally, nontraditional risk factors, mainly immunosuppressive therapy, and acute rejection episodes increased the homocystein levels, viral infection such as Citomegalovirus. Chronic allograft dysfunctions are frequent in the post-transplant follow-up. ${ }^{10}$ Presence of pre-transplant cardiovascular disease is considered an important risk factor for cardiovascular mortality after transplant. ${ }^{5,11}$

Assessment of pre-transplant cardiovascular risk is important to prevent post-transplant complications. However, there is no validated cardiovascular risk score for that group of patients. ${ }^{12}$

The aim of this study was to analyze cardiovascular risk pre and one-year after transplant, by Framingham score, in a cohort of kidney transplant recipients.

\section{PATIENTS AND METHODS}

Retrospective, single center study based on analysis of medical records from renal transplant recipients in a Renal Transplant Unit in the São Paulo state.

Inclusion criteria: (a) renal transplant from January/2010 and January/2012, (b) age $>18$ years old at the transplant, (c) functioning graft at the end of 12-months follow-up.

Exclusion criteria: (a) pediatric recipient, (b) graft loss or patient death $<12$ months post-transplant.

Analyzed data: age, etiology of the chronic kidney disease, length of pre-transplant dialysis, donor source (living related or deceased), cold ischemia time, immediate or delayed graft function. In order to calculate the Framingham score, ${ }^{12}$ data was collected as to the gender, age, systolic blood pressure, use of anti-hypertensive drugs, smoking, presence of diabetes, total and HDL cholesterol. Non-traditional risk factors including serum uric acid, serum calcium and phosphate, PTH levels, and echocardiogram data such as ejection fraction, left ventricular hypertrophy and vascular calcification were obtained. All cardiovascular events within the first post-transplant year were recorded.

Data was collected for two distinct time points: baseline, defined as pre transplant data and oneyear after transplant. Cardiovascular risk was assessed by Framingham score (2008), at baseline and one-year after transplant, using the $Q x$ calculator application.

Statistical analysis: Data was presented as mean \pm standard deviation. Data analysis was performed by SPSS-V..$^{13}$ software, using a t-student list and statistical significance considered whenever $p<0.05$.

\section{RESULTS}

From January 2010 to January 2012, 230 isolated renal transplants were performed in adult patients. From these, 167 fulfilled the inclusion criteria and were included in the analysis. Sixty-three patients were excluded due to patient or graft loss within the first year after transplant $(n=29)$, and incomplete data to be analyzed $(n=34)$. The majority of patients were male $(n=108,64.6 \%)$, recipients from deceased kidney transplant $(n=162,97 \%)$, with mean age of $47.9 \pm 11.1$ years old. Etiology of CKD included systemic hypertension $(n=50,29.9 \%)$, chronic glomerulonephritis $(n=34,20.3 \%)$, diabetes $(n=21$, $12.5 \%)$, polycystic renal disease $(n=12,7.2 \%)$, chronic pyelonephritis $(n=9,5.4 \%)$, unknown etiology $(n=31$, $18.5 \%)$ and other causes $(n=10,5.9 \%)$. Mean length of dialysis therapy was of $53.9 \pm 45.1$ months.

Analysis of non-traditional risk factors at baseline showed increased PTH levels (542.2 $\pm 603.2 \mathrm{pg} / \mathrm{dL})$, hypocalcemia (serum calcium $8.4 \pm 0.7 \mathrm{mg} / \mathrm{dL}$ ) and hyperphosphatemia (serum phosphate $5.9 \pm 6.5 \mathrm{mg} /$ $\mathrm{dL}$ ), with a calcium $x$ phosphate product of $50.8 \pm 65.8$ $\mathrm{mg} / \mathrm{dL}$. Echocardiogram was performed in 118 patients, with a common finding of left ventricular hypertrophy $(56.8 \%)$, with $67.5 \pm 6.6 \%$ mean ejection fraction. Vascular calcification in the aortic ring was noticed in two cases and mitral ring calcification in one. There was no description of valve ring calcification in the remaining tests.

Framinghan score was comparable in both analyzed time points. However, analysis of individual parameters showed a significant difference. Pretransplant risk factors were blood pressure, lower HDL and smoking. Post-transplant risk factors included presence of diabetes, high total cholesterol levels and amount of patients receiving drugs to treat hypertension. [Table 1]. 
Table 1: Framinghan score risk parametes, pre and one year after transplant.

\begin{tabular}{|c|c|c|c|}
\hline Parameter & Pre transplant & 1-year post transplant & $\mathbf{P}$ \\
\hline Number of patients & 167 & 167 & \\
\hline Framinghan score & $16.4 \pm 14.9$ & $18.3 \pm 17.2$ & 0.2 \\
\hline Systolic blood pressure (mmHg) & $139.9 \pm 22.0$ & $130.8 \pm 18.9$ & $\mathrm{p}<0.05$ \\
\hline Hypertension therapy (\%) & $136(80.9 \%)$ & $150(89,2 \%)$ & $\mathrm{p}<0.05$ \\
\hline Number of anti hypertensive drugs & $2.12 \pm 1.15$ & $2.26 \pm 1.04$ & 0.2 \\
\hline RAS blockade [n,(\%)] & $56(41.1 \%)$ & $26(11,3 \%)$ & $\mathrm{p}<0.05$ \\
\hline Smoking [n,(\%)] & 55 (32.9\%) & $48(28,7 \%)$ & 0.4 \\
\hline Diabetes [n,(\%)] & $28(16.7 \%)$ & $56(33,5 \%)$ & $\mathrm{p}<0.05$ \\
\hline HDL cholesterol (mg/dL) & $38.8 \pm 11.6$ & $47.2 \pm 13.2$ & $p<0.05$ \\
\hline LDL cholesterol (mg/dL) & $156.9 \pm 41.9$ & $199.1 \pm 44.2$ & $\mathrm{p}<0.05$ \\
\hline Uric acid (mg/dL) & $5.8 \pm 1.6$ & $6.5 \pm 1.47$ & $\mathrm{p}<0.05$ \\
\hline Calcium $x$ phosphate product (mg/dL) & $45.9 \pm 14.6$ & $30.8 \pm 6.7$ & $p<0.05$ \\
\hline Hematocrit (\%) & $33,5 \pm 6,8$ & $42.9 \pm 6.1$ & $p<0.05$ \\
\hline
\end{tabular}

RAS- renin angiotensin system, $\mathrm{n}=$ number.

\section{DISCUSSION}

Cardiovascular complications are the main cause for mortality in chronic kidney disease patients, in dialysis therapy or after transplant. Traditional and non-traditional risk factors, such as bone mineral metabolism disorders increase the chance for vascular calcification and ischemic cardiovascular events in dialysis.1,13 In theory, after a successful transplant, specific CKD associated disorders are corrected, and recovery of anemia, normalization of the calcium-phosphate metabolism and correction of systemic acidosis and hypervolemia could result in a reduction of traditional and nontraditional risk factors, reducing cardiovascular events after transplant ${ }^{\mathrm{t} 10,14}$ However, kidney transplant per se is associated to new risk factors, usually side effects of immunosuppressive therapy or as consequence of weight gain commonly observed in those patients. ${ }^{3,15}$

Pre-transplant risk factors in this series increased the calcium phosphate product that could be associated to an increased risk for vascular calcification, especially for large arteries such as aorta, iliac and carotid, as well as for coronary ischemic disease. ${ }^{11,13}$ Vascular calcification increases the risk for ischemic disease, such as ischemic heart disease, stroke or peripheral arterial obstruction. In this series, we were unable to observe an increased incidence of valve calcification in the analyzed echocardiograms.

Hypertension was frequent both pre and post-transplant. However, the amount of patients receiving antihypertensive drugs after transplant was higher than in the pre transplant group. In addition, blood pressure levels are lower after transplant. One possible explanation for this increased use of the post-transplant therapy is the need for lower blood pressure levels in order to keep the best kidney function. Also, pre-transplant hypervolemia is common, and usually corrected with efficient dialysis, with lower need for anti-hypertensive drugs. $5,6,10$

Post-transplant changes are mainly metabolic, and they can be attributed to the use of immunosuppressive therapy with steroids and calcineurin inhibitors that modulates the glucose metabolism leading to an increase in the peripheral resistance to insulin. In patients receiving tacrolimus, the insulin synthesis by pancreatic $\beta$ cells are also impaired, with a more difficult glucose control. In the early after kidney transplant, we observed a recovery of nutritional status because of control of the systemic acidosis and malnutrition of 
chronic renal disease. ${ }^{4,8-10}$ This recovery of appetite is usually associated to an increase in body weight, as well as to the development of metabolic disease, markedly hyperlipidemia, hyperuricemia and glucose intolerance. Recovery of renal function is associated to an improvement of hematological parameters and volume control, reducing the incidence of congestive heart disease. However, risk for ischemic cardiovascular disease persists, as the preexisting vascular calcification is kept. ${ }^{11,13-15}$

\section{CONCLUSION}

Taken together, those data suggest that despite of recovery of some risk factors from Framingham score with a successful kidney transplant, new risk factors appear after transplant, maintaining the estimated score. The use of the Framingham score to assess cardiovascular risk in such group of patients should be carefully considered, especially as the renal function is not considered a marker for cardiovascular disease in this formula.

\section{RESUMO}

Mortalidade cardiovascular é a principal causa de perda de enxerto após o transplante renal. Objetivo: Avaliar o risco de eventos cardiovasculares, utilizando o escore de Framinghan pré e 12 meses pós transplante renal. Métodos: Estudo retrospectivo, avaliando banco de dados de transplantes renais realizados entre janeiro/2010 e janeiro/2012. Critérios de inclusão: idade > 18 anos, rim funcionante ao final de um ano. Exclusão: perda de enxerto ou óbito < 12 meses. Parâmetros demográficos e laboratoriais foram coletados pré e pós 12 meses, e o escore de Framinghan foi calculado nos mesmos pontos. Ecocardiograma pré-transplante também foi avaliado. Resultados: De 230 transplantes renais realizados no período de estudo, 167 preencheram os critérios de inclusão, e 63 foram excluídos por perda de enxerto e/ou óbito do receptor < 12 meses $(n=29)$ ou dados insuficientes para análise. Os pacientes avaliados eram na maioria homens

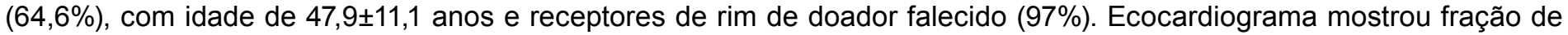
ejeção de $67,5 \pm 6,6 \%$, hipertrofia ventricular esquerda em $98 \%$, porém com calcificação valvar rara $(2,5 \%)$. O escore de Framinghan foi comparável pré e pós-transplante $(16,4 \pm 14,9$ vs. $18,3 \pm 17,2$, $p=n s)$, porém com diferença significativa na análise individual dos parâmetros. Os indicadores de risco mais importantes pré-transplante foram pressão arterial, HDL colesterol baixo e tabagismo, enquanto que, ao final de um ano, destacou-se a presença de diabetes, colesterol total elevado e uso de medicação anti-hipertensiva. Conclusão: No período precoce após o transplante, normalização da função renal, recuperação de hematócrito e recuperação nutricional resultam em maior ganho ponderal, porém com piora dos parâmetros metabólicos, principalmente de colesterol total, triglicérides e ácido úrico, o que mantém o risco estimado pelo escore de Framinghan semelhante ao observado pré-transplante.

Descritores: Transplante; Doenças Cardiovasculares; Medição de Risco. 


\section{REFERENCES}

1. Miller LM, Sood MM, et al. Cardiovascular disease in end-stage renal disease: the challenge of assessing and managing cardiac disease in dialysis patients. Int Urol Nephrol 2010;42:1007-14.

2. Mattos AM, Prather J, et al. Cardiovascular events following renal transplantation: Role of traditional and transplant-specific risk factors. Kidney International 2006;70:757-64.

3. Marcén R. Cardiovascular risk factors in renal transplantation: current controversies. Nephrol Dial Transplant 2006;21(Suppl 3):iii3-iii8.

4. Pádua Netto MV, Campos Bonfim TC, Costa EN, de Lima HV, Neto LC. Cardiovascular risk estimated in renal transplant recipients with the Framingham Score. Transplant Proceed 2012:44(8):2337-40.

5. Gowdak LHW, De Paula FJ, et al. Doença cardiovascular e fatores de risco cardiovascular em candidatos a transplante renal. Arquiv Bras Cardiol 2005;84(2):

6. Fellström B, Jardine AG, Soveri I, et al. Renal dysfunction is a strong and independent risk factor for mortality and cardiovascular complications in renal transplantation. Am J Transplant 2005;5:1986-91

7. Aalten J, Hoogeveen EK, Roodnat JI et al. Associations between pre-kidney-transplant risk factors and posttransplant cardiovascular events and death. Transplant Int 2008;21(10):985-91.
8. Krämer BK, Böger C, Kruger B et al. Cardiovascular risk estimates and risk factors in renal transplant recipients. Transplant Proceed 2005;37(4):1868-70.

9. Gill JS. Cardiovascular disease in transplant recipients: current and future treatment strategies. Clin J Am Soc Nephrol 2008;3:S29-S37,

10. Rigatto C, Parfrey P. Therapy insight: management of cardiovascular disease in the renal transplant recipient. Nat Clin Practice Nephrol 2006;2:514-26.

11. O Leonard, J Spaak et al. Regression of vascular calcification in chronic kidney disease: feasible or fantasy? A review of the clinical evidence. British $\mathrm{J}$ Clin Pharmacol 2012;

12. Wilson PWF, D'Agostino RB, Levy D et al. Prediction of coronary heart disease using risk fator categories. Circulation 1998;97:1837-47.

13. Roe $\mathrm{P}$, Wolfe $\mathrm{M}$, et al. Inflammation, coronary artery calcification and cardiovascular events in incident renal transplant recipients. Atherosclerosis 2010;121(2):589-94.

14. Banas MC, Banas B, Orth SR et al. Traditional and non traditional risk factors and estimated risk for coronary artery disease in renal transplant recipients: a single center experience. Nephron Clin Practice 2011;119(3):c227-35.

15. Ducloux D, Kazory A, Chalopin JM. Predicting coronary heart disease in renal transplant recipients: a prospective study. Kidney Int 2004;66(1):441-7. 